\title{
Long-distance aeromedical repatriation of women at risk for preterm labor and delivery
}

\author{
Alex Veldman ${ }^{1,2,3 *}$, Ryan Hodges ${ }^{3,4}$, Michael Diefenbach ${ }^{1}$, Cornelia Rohrbeck ${ }^{1}$, Ruby Pannu ${ }^{1}$, Sophie Schmitt-Kästner ${ }^{2}$ and Doris Fischer $^{2,5}$ \\ ${ }^{1}$ Jetcall, Idstein, Germany \\ ${ }^{2}$ Department of Pediatrics, St. Vincenz Hospital, Limburg, Germany \\ ${ }^{3}$ The Ritchie Centre, Hudson Institute of Medical Research, Monash University, Melbourne, Australia \\ ${ }^{4}$ Department of Obstetrics \& Gynaecology, Monash University, Melbourne, Australia \\ ${ }^{5}$ Department of Pediatrics, J.W. Goethe University, Frankfurt, Germany
}

\begin{abstract}
Pregnant women, like everyone else, travel internationally for business and pleasure. However, since preterm labor is experienced in 8-30\% of all pregnancies, a significant number of women are admitted to hospitals with signs and symptoms of threatening preterm delivery while traveling abroad. Repatriation requests represent a difficult scenario for insurance and assistance companies as well as for physicians in referring and admitting hospitals. Here, we present a comprehensive literature review and an analysis of possibilities and limitations when transporting pregnant women on international, long-distance fixed-wing Air Ambulance.

While no Air Ambulance environment can provide the necessary safety for mother and baby during a delivery in-flight, available data suggests that in-flight deliveries can be successfully avoided. In this review, we propose a risk based approach, taking factors such as locally available perinatal services, transport distance and routing, presence or absence of chorioamnionitis and contractions, cervical length and cervical dilatation as well as molecular markers (fFN, PAMG-1, phIGFBP-1), if locally available, into account.
\end{abstract}

\begin{abstract}
Abbreviations: CAMTS: Commission on Accreditation of Medical Transport Systems, COXII: Cyclooxygenase-2, EURAMI: European Aeromedical Institute, fFN: fetal Fibronectin, GA: Gestational Age, HFO: High Frequency Oscillation, ICU: Intensive Care Unit, iNO: inhaled Nitric Monoxide, PAMG-1: Placental alpha-microglobulin-1, phIGFBP-1: Cervical phosphorylated insuline-like growth factor binding protein-1, PROM: Premature Rupture of Membranes, RCT: Randomized Controlled Trial, RFDS: Royal Flying Doctor Service, ROM: Rupture of Membranes.
\end{abstract}

\section{Introduction}

International traveling was steadily increasing in the past: The International Civil Aviation Organization (ICAO) reported that airlines carried 4.3 billion passengers in 2018 , which is 6.4 per cent higher than the previous year, while the number of departures reached 37.8 million in 2018. Accordingly, an increasing number of women are traveling during pregnancy. In some studies, more than $50 \%$ of pregnant women traveled abroad during their pregnancy; with over a third of those embarking on long distance, intercontinental journeys [1].

In general, air travel is safe in pregnancy. The second trimester between 14 and 28 weeks is mostly recommended as a particular safe period for traveling [2]. Major commercial airlines accept pregnant women until 36 weeks gestational weeks (GA) on board scheduled flights. However, the risk of preterm delivery (birth prior to 37 weeks GA) is currently estimated at approximately $8 \%$ in a first observed pregnancy with an increased risk up to $30 \%$ in women with a history of preterm delivery [3]. Consequently, a significant number of women at risk for preterm labor are admitted into hospital while traveling abroad, with the main reason for admission being spontaneous onset of labor with contractions, rupture of membranes, cervical shortening and/or dilatation or any combination of the previous. In such cases, aeromedical repatriation to the respective home country or a location with high quality obstetric services by fixed wing air ambulance is frequently requested. This paper reviews the risk of delivery en-route, the optimal management of repatriation requests for women at risk for preterm labor and delivery and evaluates possible transport scenarios using a risk-based approach.

\section{In-flight delivery}

Stay or transport: Even in the most sophisticated and spacious airambulance aircraft (e.g. Bombardier Challenger 604 or similar, Figure 1), acceptance of the risk of (and planning contingencies for) a delivery in-fight is not an option. An in-flight delivery is prohibitive due to an excessive risk for mother and fetus, poor monitoring capabilities of fetal wellbeing, non-existent possibilities to escalate to an assisted vaginal delivery and/or caesarian section if needed and very limited options for the management of post-partal and post-natal complications, in particular maternal post-partum hemorrhage.

The main consideration for any woman with threating preterm labor abroad is therefore the decision to either repatriate to the country of origin, alternative to the nearest country with advanced obstetric

${ }^{*}$ Correspondence to: Alex Veldman, FRACP, Medical Director, Jetcall, Walramstr. 21, 65510 Idstein, Germany, E-mail: avn@jetcall.eu

Key words: preterm labor, aeromedical repatriation, air ambulance, fixed wing

Received: April 18, 2020; Accepted: May 27, 2020; Published: June 02, 2020 


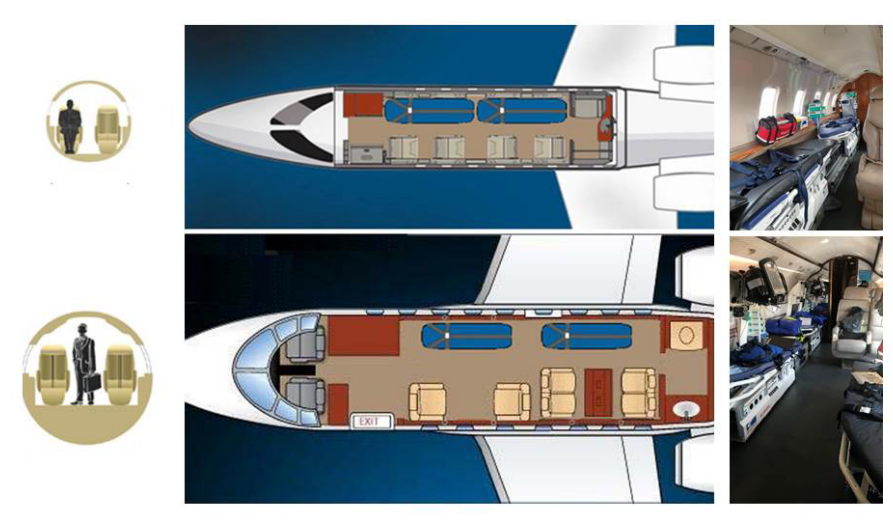

Figure 1. Air ambulance interior configurations and cabin cross sections

Interior Configuration and Cabin Cross Section of a medium large (Bombardier Learjet 45, upper panel) and large Air Ambulance Aircraft (Bombardier Challenger 604, lower panel). Note that the max. cabin height in the Learjet 45 is $149 \mathrm{~cm}$, in the Challenger $604186 \mathrm{~cm}$. The max. cabin width in the Learjet 45 is $155 \mathrm{~cm}$, in the Challenger $604250 \mathrm{~cm}$

services (in-utero transfer of the fetus) or to stay in the current location and transport mother and baby home after delivery (post-natal transfer of the newborn). A number of important variables influence the balanced risk-benefit analysis of such a decision (Table 1).

While most of these variables are relatively easy to identify, the ability to predict the risk for delivery is an area of ongoing debate. However, despite a significant number of in-utero /antenatal transfers of term and pre-term fetuses, the number of reported births in-flight is surprisingly low, pointing towards some accuracy is assessing the risk of delivery en-route. Tsokos et al. [4] published a study on 99 consecutive aeromedical maternal transfers in Western Australia in 1988, with no reported delivery during transport. An analysis of the Australian Royal Flying Doctor Service in 453 antenatal transfers for threating delivery (preterm or term, 90\% emergency) from rural Australia to metropolitan areas also did not document a single delivery in-flight [5].

A second analysis of RFDS Australia on 500 consecutive transfers of women at risk of preterm labor to the tertiary referral center, from September 2007 to December 31, 2009 again confirmed no deliveries in-flight. Cervical dilatation $>/=4 \mathrm{~cm}$, ruptured membranes, gestational age $>32$ weeks and, surprisingly, nulliparity were identified as risk factors associated with a shorter time from landing to subsequent delivery [6]. An older report published by the US Air Force analyzed 329 long range transports of obstetric patients at various gestational ages with no delivery or other complications occurring in-flight [7]. More recent Canadian data on 121 maternal aeromedical transfers, 63\% of them for either threatening preterm labor or premature rupture of membranes confirmed no deliveries during transfer and also showed that women transferred for threatening preterm labor were significantly less likely than those transferred for all other reasons to need delivery at the admitting hospital (RR 0.44 [0.30-0.65], $\mathrm{P}<0.0001$ ) [8]. A paper from a US based program on 80 long-distance fixed-wing transport of obstetrical patients did not report deliveries in-flight and listed a number of minor complications with nausea and vomiting being most frequent ( $80 \%$ of transported women), followed by increased contractions in $8.8 \%$ of transported women [9]. In our own experience, international long-haul transfer of 10 pregnant women in fixed winged air ambulance aircraft with flying times between 2.5 and 5.5 hours did not result in any in-flight delivery or the need to divert the plane to a nearby destination (Table 2).

\section{Predicting the risk of preterm delivery}

\section{Preterm uterine contractions}

Preterm contractions with spontaneous cessation occur in up to $30 \%$ of all pregnancies and do not predict preterm birth per se. However, amongst women with cervical shortening, uterine contractions were indeed identified as a risk factor for preterm delivery [10]. Therefore, other parameters in combination with the occurrence of regular contractions are necessary to clarify the risk of preterm birth within the next 7 days and consecutively to initiate tocolysis.

\section{Rupture of membranes (ROM)}

Spontaneous rupture of membranes accelerates labor and predicts much faster progress in multipara women $>37$ weeks of gestation. The clinically impression is that ROM signals the descent of fetal parts and

Table 1. Variables to consider in the decision between in-utero or post-natal transfer

\begin{tabular}{|c|c|c|}
\hline Variable & Favors in-utero transfer & Favors post-natal transfer \\
\hline Acutely of labor & low & high \\
\hline $\begin{array}{c}\text { Quality of local obstetric } \\
\text { and neonatal services in } \\
\text { relation to gestational age }\end{array}$ & low & high \\
\hline $\begin{array}{c}\text { Quality of local obstetric } \\
\text { services in relation to } \\
\text { known maternal and } \\
\text { fetal risk factors and co- } \\
\text { morbidities }\end{array}$ & low & high \\
\hline $\begin{array}{c}\text { Distance and anticipated } \\
\text { transport times }\end{array}$ & short & long \\
\hline $\begin{array}{c}\text { Available options for } \\
\text { diverting the flight in case } \\
\text { of unforeseen progression } \\
\text { of labor }\end{array}$ & alternate airfields available & alternate airfields not \\
available
\end{tabular}

Table 2. Characteristics of 10 in-utero transfers by Jetcall Air Ambulance between 01/2015 and $01 / 2020$

\begin{tabular}{|c|c|c|c|c|}
\hline $\begin{array}{l}\text { GA of the fetus } \\
\text { at transfer } \\
\text { (weeks) }\end{array}$ & Routing & $\begin{array}{l}\text { Flight time } \\
\quad(\min )\end{array}$ & $\begin{array}{l}\text { Reason for } \\
\text { transfer }\end{array}$ & $\begin{array}{c}\text { Tocolysis } \\
\text { during } \\
\text { transport }\end{array}$ \\
\hline $30+6$ & $\begin{array}{c}\text { Faro (P) London } \\
\text { (UK) }\end{array}$ & 170 & PROM & no \\
\hline $35+4$ & $\begin{array}{c}\text { Tunis (T) } \\
\text { London (UK) }\end{array}$ & 240 & $\begin{array}{c}\text { PROM, } \\
\text { contractions, (nil } \\
\text { at transfer) }\end{array}$ & no \\
\hline $21+2$ & $\begin{array}{c}\text { Ibiza (E) } \\
\text { London (UK) }\end{array}$ & 150 & PROM & no \\
\hline $25+0$ & $\begin{array}{c}\text { Crete (GR) } \\
\text { Trollhattan (NO) }\end{array}$ & 270 & $\begin{array}{l}\text { Vaginal } \\
\text { Bleeding, } \\
\text { retroplacental } \\
\text { hematoma, } \\
\text { contractions (nil } \\
\text { at transfer) }\end{array}$ & no \\
\hline $29+0$ & $\begin{array}{l}\text { Florence (I) } \\
\text { Alborg (DK) }\end{array}$ & 120 & $\begin{array}{c}\text { PROM, } \\
\text { contractions (nil } \\
\text { at transfer) }\end{array}$ & yes (Atosiban) \\
\hline $23+4$ & $\begin{array}{l}\text { Heraklion (GR) } \\
\text { Paderborn (D) }\end{array}$ & 180 & $\begin{array}{c}\text { Vaginal } \\
\text { Bleeding }\end{array}$ & no \\
\hline $21+6$ & $\begin{array}{c}\text { Lisbon (P) } \\
\text { Bristol (UK) }\end{array}$ & 180 & Preeclampsia & no \\
\hline $24+4$ & $\begin{array}{l}\text { Athens (GR) } \\
\text { Amsterdam } \\
(\mathrm{NL})\end{array}$ & 180 & $\begin{array}{c}\text { Vaginal } \\
\text { Bleeding, } \\
\text { Placenta Previa }\end{array}$ & no \\
\hline $34+0$ & $\begin{array}{c}\text { Paphos (CY) } \\
\text { Liverpool (UK) }\end{array}$ & 330 & $\begin{array}{c}\text { Fetal } \\
\text { Abnormalities }\end{array}$ & no \\
\hline $28+3$ & $\begin{array}{l}\text { Athen (GR) } \\
\text { Cologne (D) }\end{array}$ & 190 & $\begin{array}{c}\text { Contractions (nil } \\
\text { at transfer), Fetal } \\
\text { Abnormalities }\end{array}$ & no \\
\hline
\end{tabular}


accelerates cervix dilatation. A likely mechanism is the reduction of uterine wall tension by reduction of the intrauterine volume according to the Law of LaPlace [11]. This enables the uterus to generate higher pressure, resulting in an acceleration of labor [12]. In about $70 \%$ of cases; premature rupture of membranes (PROM) is associated with intra-amniotic infection. Several tests are available to confirm the diagnosis of PROM (see below) but a method to reliably predict PROM is not available. Additionally, the prediction of preterm birth solely based on the occurrence of PROM is not possible [13].

\section{Cervical length}

Cervical length measurement can easily be performed by transvaginal ultrasound. Shortening of cervix uteri has been associated with an increased risk of preterm birth [14] and a recently published small study of singleton nulliparous woman reported on the possibility to predict preterm delivery within 7 days solely based on sonographic findings [15]. However, in a meta-analysis of women with twin pregnancies and symptoms of spontaneous preterm birth, cervical length hat a low predictive accuracy for preterm birth $<34$ weeks of gestational age (GA) [16].

\section{Cervical dilatation}

Cervical dilatation is a commonly used predictor for the risk of preterm delivery. In a study on women presenting for threating preterm labor at a mean gestational age of $28.1+/-2.9$ weeks, cervical dilatation of 0 to $1 \mathrm{~cm}$ was associated with $6 \%$ of the women delivering within 48 hours, $20 \%$ delivering at $<32$ weeks, and $38 \%$ delivering at $<35$ weeks. With cervical dilatation of 6 to $10 \mathrm{~cm}, 89 \%$ delivered in $<24$ hours, $11 \%$ between 24 and 48 hours, $94 \%$ delivered at $<32$ weeks, and $100 \%$ delivered at $<35$ weeks [17].

\section{Fetal fibronectin (fFN)}

Fibronectin, a high molecular glycoprotein is necessary for embryogenesis and important for guiding cell attachment and migration during embryonic development. Fetal fibronectin is found at the interface of the chorion and the decidua. A positive qualitative fFN-test in the cervicovaginal fluid is associated with an increased risk for premature birth, but the sensitivity and the positive predictive value of the test are low [18]. Among nulliparous women with singleton pregnancies, even the combination of quantitative fFN levels and cervical length had low predictive accuracy for spontaneous preterm birth [19]. In twin pregnancies, fetal fibronectin alone failed in terms of prediction accuracy and is not recommended for twin pregnancies $[20,21]$. The combination of evidence of fFN together with cervical length was shown to be effective in predicting birth before 34 weeks in twin pregnancies, but not accurately predicting the time interval between examination and delivery [22].

\section{Cervical phosphorylated insuline-like growth factor binding protein-1 (phIGFBP-1)}

Insulin like growth factors and their binding proteins are important for placental and fetal growth and development. PhIGFBP-1 is synthesized in decidualized endometrium cells. Uterine contractions are leading to tissue disruptions at the choriodecidual interface and can result in a leakage of phIGFBP-1 into cervical secretions. Although a negative phIGFBP-1 test was found to have a potential utility to identify patients who will not deliver within 48 hours, its overall predictive ability is limited. The combination of phIGFBP- 1 together with cervical length had also a low predictive accuracy to predict preterm birth [21,23].

\section{Placental alpha-microglobulin-1 PAMG-1}

Placental alpha-1 Microglobulin (PAMG-1) is a protein with a high concentration in amniotic fluid as well as in membranes of the chorion. The presence of placental alpha macroglobulin-1 in the vagina specifically indicates a disruption in the integrity of the fetal membranes and may indirectly designate an increased risk for preterm birth [24]. Cervical PAMG-1 had a high accuracy to predict preterm birth within 7 and $14 \mathrm{~d}$ of testing in symptomatic pregnant women. In women with cervical length of $15-30 \mathrm{~mm}$, the predictive value of PAMG-1 regarding delivery within the next 7 days was superior to fFN and PhIGFBP-1 ( $69,4 \%$ vs. $28,8 \%$ vs. $25,4 \%$ ) [25].

\section{Combination of parameters}

Despite the limitation in terms of predicting preterm birth, cervical ultrasound is routinely performed in women with signs of preterm labor. If assessment of cervical fluid is performed, fFN testing is most frequently used. The German Society of Gynecology and Obstetrics is using these two parameters to stratify women with threating preterm labor into two risk groups (Table 3). Another study identified the following risk factors for delivery within $48 \mathrm{~h}$ after starting tocolysis: cervical dilatation at admission, elevated leukocyte count at admission, and developing signs suggestive of chorioamnionitis following admission.

\section{Secondary and tertiary prevention of preterm delivery in the hospital and pre-flight setting}

\section{Progesterone}

Progesterone has been shown to be effective in terms of prevention of preterm birth without negative effect on neurocognitive development of the fetus if administered intravaginal in asymptomatic women with singleton pregnancy and reduced cervical length $<25$ $\mathrm{mm}$ at gestational age $<24+0$ weeks [26-28]. Unfortunately, data for pregnancies $>24+0$ weeks GA and reduced cervical length $<$ $25 \mathrm{~mm}$ are not consistent. In multiple pregnancies, progesterone has not been proven as useful for preventing preterm birth20. Therefore, daily vaginal administered progesterone (200 mg capsula/day or 90 mg gel) is recommended by the German, Swiss an Austrian societies of Gynecology and Obstetrics only for singleton pregnancy with reduced cervical length $<25 \mathrm{~mm}$ at an gestational age of $<24+0$ weeks GA [29].

\section{Cerclage}

Cerclage hast been extensively in the focus of research with the aim to identify the group of pregnant women who would benefit most from cerclage. In multiple pregnancies, mixed results in the use of cerclage including harmful events have been reported [20,30]. Women with singleton pregnancy, without history of preterm labor and reduced cervical length $<25 \mathrm{~mm}$ at $<24+0$ weeks GA seem not to profit from cerclage [31]. Cerclage is recommended in women with a history of spontaneous vaginal preterm delivery, singleton pregnancy and reduced cervical length $<25 \mathrm{~mm}$ at $<24+0$ weeks GA [29].

Table 3. Stratification of women with threating preterm labor into two risk groups by the German Society of Gynecology and Obstetrics

\begin{tabular}{|c|c|}
\hline Low risk & $\begin{array}{c}\text { Cervical length }>30 \mathrm{~mm} \text { or Cervical length } \\
15-30 \mathrm{~mm} \text { and negative } \mathrm{fFN} \text {-Test }\end{array}$ \\
\hline Elevated risk & $\begin{array}{c}\text { Cervical length }<15 \mathrm{~mm} \text { or Cervical length } \\
15-30 \mathrm{~mm} \text { and positive } \mathrm{fFN} \text {-Test }\end{array}$ \\
\hline
\end{tabular}




\section{Cervical pessary}

In a 2017 published trial, cervical pessary seemed to be as effective as vaginal progesterone in women with singleton pregnancy and reduced cervical length $<25 \mathrm{~mm}$ at $<24+0$ weeks GA [32]. National guidelines describe the use of cervical pessary as potential option in those patients [29]. The evidence for the use of cervical pessary in twins is conflicting; a RCT in the UK with the aim to analyze the effect of cervical pessary in twin pregnancy is ongoing [33].

\section{Tocolysis}

The aim of tocolysis is definitely not to prevent preterm birth but to prolong pregnancy for at least for 48 hours to provide a complete course of antenatal steroids to the fetus and to enable an in-utero transport into a perinatal center [34]. There is a clear recommendation for tocolysis between $22+0$ and $33+6$ weeks GA on in case of spontaneous contractions ( $>4$ contractions $/ 20 \mathrm{~min}$ ) in combination with cervical dilatation and/or reduced cervical length and the absence of contraindications like fetal hypoxia, chorioamnionitis, pre-eclampsia, severe maternal bleeding or cervical dilatation $>4 \mathrm{~cm}$ $[29,35]$. The effects on prolongation of pregnancy, maternal and fetal safety and neonatal mortality of drugs like B-sympathicomimetica, COXII -Inhibitors (indomethacine), calcium-antagonists (nifedipine), magnesiumsulfate, oxytocin receptor antagonist (atosiban) and NOdonators have been examined in more than 95 RCTs. Already in 1988, Tsokos et al. [4] published a study on 99 consecutive aeromedical maternal transfers in Western Australia in which B-sympathicomimetic inhibition of uterine activity was achieved successfully and only one case of pulmonary edema and 2 cases of maternal hypoglycemia were documented. However, because of the significant higher rates of maternal adverse reactions (especially pulmonary edema) of ß-sympathicomimetica and the dose-dependent efficacy and side effects of magnesiumsulfate, both substances are not recommended for tocolysis anymore [36,37]. Atosiban has the same efficacy like ß-sympathicomimetica or nifedipine but a significant lower risk of side effects for both mother and fetus and is therefore recommended as first line tocolytic agent in Germany $[29,37]$ or as tocolytic agent of choice in case of contraindications against nifedipine or indomethacine. However, Atosiban has not yet been approved in US.

The COX II Inhibitor Indomethacine has a high tocolytic efficacy with low maternal side effects; however, according to the risk of intrauterine closure of the fetal ductus arteriosus the use is limited to pregnancies $<32$ weeks GA and a treatment course of 48 hours [38].

Nifedipine has been shown to be an effective tocolytic agent without documented negative effects on neonatal mortality or morbidity. The recommended oral dosage is initial $10 \mathrm{mg}$, followed by 10-20 mg 3-4 times daily [29]. Because of the possible oral administration it seems to be the drug of choice especially in the outpatient setting. Severe cardiovascular side effects like arterial hypotonia, tachycardia and lung edema are reported, especially in combination with antenatal steroids or a cumulative dose $>160 \mathrm{mg} /$ day. Even at a cumulative dose $60 \mathrm{mg} /$ day, a threefold increased risk of tachycardia and an 8-9 fold increased risk of arterial hypotonia is observed. Therefore, the use of nifedipine in women with preexisting cardiovascular diseases or arterial hypotonia is critical and all pregnant women receiving nifedipine require circulatory monitoring [37,39].

The combination of several tocolytics, the combination of tocolytics with progesterone and the use of prolonged tocolysis for more than 48 hours is not recommended [40].

\section{Scenario planning (I): Elective delivery prior to transport}

In women with highly acute labor, in-utero transfer of the fetus is no longer an option since delivery en-route carries an unacceptable risk to mother and baby and must be avoided at all costs.

Depending on the quality of locally available obstetric services in relation to gestational age and to know maternal and fetal risk factors and co-morbidities, support by sending an obstetric / neonatal team for a planned delivery with full equipment (incubator, surfactant, HFO, iNO, etc.) might be considered in exceptional circumstances. Since the risk for intraventricular hemorrhage in extremely preterm babies is particular high in the first 72 hours of life, minimal handling is recommended in this period and inter-facility transfers are discouraged, making a prolonged stay of the neonatal team a necessity in some very high risk infants. Combined transports of mother and baby may be a possibility in large body air ambulance aircraft such as the Bombardier Challenger 604 and others (Figure 1).

\section{Scenario planning (II): Diverting a transport}

In our own practice, careful assessment of the acuity of labor, taking into account all available information on cervical length and dilatation, rupture of membranes, need for tocolysis prior to transfer, active amnion infection syndrome, molecular markers etc., was $100 \%$ effective to prevent in-fight deliveries. Our current protocol stipulates tocolysis in stand-by during the transport of a pregnant woman with threating pre-term delivery. If the air ambulance team would observe any signs of progression into labor (such as re-occurrence of active contractions), the patient is started on tocolysis. Depending on the efficacy of tocolysis and the location of the aircraft in relation to the planned destination, the fight may be diverted to the nearest facility with adequate obstetric and neonatal services depending on the gestational age and additional risk factors of the individual pregnancy. Planning of alternative airfields / destinations for different sectors of the flight with decision-points to switch from one to the next potential alternative destination prior to the transport allows quick and accurate decision making. Advanced communication equipment such as satellite telephones and messaging services enable the team to efficiently communicate with ground services and arrange ambulance pick-up and admission while still in the air.

\section{Discussion and recommendations}

The freedom to travel is a fundamental right that shall be not be restricted while experiencing the gift of pregnancy. Since the second trimester is considered a particularly safe period for traveling, we will continue to experience a significant number of women who, while traveling abroad, develop signs and symptoms of threating preterm labor. If such an event occurs, either delivery abroad or in-utero transfer to either the home country or the nearest center that can provide adequate perinatal services are the only options since an anticipated delivery en-route cannot be conceived without an unacceptable risk to mother and fetus.

The establishment of regionalized high-level perinatal care in many countries, with thousands of women with threating preterm delivery being successfully transferred to centers with higher levels of care, is convincing evidence that it is possible to predict the short-term risk for delivery relatively accurate. However, in contrast to regional transfers that are usually completed within a few hours, an international repatriation of a woman with threating preterm delivery might span 
a period of $24 \mathrm{~h}$ or more from decision making until arrival in the admitting hospital, which means that criteria for local and reginal transfers may not uniformly being applied to international transports.

Nevertheless, our own data as well as the published literature support the hypothesis that long-distance aeromedical repatriation of women at risk for preterm labor and delivery can be performed with reasonable safety.

We suggest the following criteria as indicators for possible international aeromedical repatriation (Table 4):

- No signs suggestive of developing chorioamnionitis

- No contractions in the $24 \mathrm{~h}$ prior to transport

- Negative molecular markers (fFN, PAMG-1, phIGFBP-1), if locally available

- Preserved cervix of $3 \mathrm{~cm}$ or more

or

\section{- Cervical dilatation of less than $1 \mathrm{~cm}$}

Despite the obvious assessment of the progress of labor, decision criteria to stay or transport should always critically consider local capacities in relation to gestational age and co-morbidities of fetus and mother. Above all, an open and candid discussion of all available options with parents and all other relevant stakeholders (local obstetrician, transport team including medical and flight-crew, the receiving perinatal center, as well as local teams at alternate destinations on very long repatriations) are key in planning of such an air ambulance transfer. Antenatal steroids should be administered in accordance with the relevant guidelines. Antibiotics can be considered. While tocolysis is ineffective in preventing preterm labor, delaying delivery to complete a course of antenatal steroids and secure the appropriate level of obstetric and neonatal care in the event of preterm delivery are goals that can be achieved by tocolysis [34]. Therefore, tocolysis should be in standby during the transport to extend the time-window allowing either continuing the transport to the planned destination or reaching the nearest center of adequate perinatal care in case of a progression into acute labor. Nifedipine seemed to serve as a useful tool to facilitate inutero transport, and in one study, when used as an intervention during flight, was associated with a reliable delay of delivery of $>48 \mathrm{~h}$ [41].

As all critically ill patients, women with threatening preterm labor should be transported in a well-equipped air ambulance aircraft and be accompanied by an experienced crew. Accreditation by established organizations such as EURAMI or CAMTS might be a useful quality indicator. Advanced communication equipment such a satellite

Table 4. Interpretation of Clinical Findings in women with threating preterm labor in respect to the risk to progress into delivery

\begin{tabular}{|c|c|c|}
\hline \multicolumn{2}{|c|}{ Parameter } & $\begin{array}{l}\text { Risk of progressing into } \\
\text { labor and delivery within }\end{array}$ \\
\hline \multirow{2}{*}{ Cervical dilatation } & $0-1 \mathrm{~cm}$ & low \\
\hline & $>5 \mathrm{~cm}$ & very high \\
\hline Cervical length & $\leq 15 \mathrm{~mm}$ & elevated \\
\hline \multirow{2}{*}{ Signs of amnion infection } & absent & low \\
\hline & present & elevated \\
\hline \multirow{2}{*}{$\begin{array}{l}\text { Molecular markers (fFN, } \\
\text { PAMG-1, phIGFBP-1) }\end{array}$} & negative & low \\
\hline & positive & elevated \\
\hline \multicolumn{2}{|c|}{ Multipara } & elevated \\
\hline \multicolumn{2}{|c|}{ Twin or Triplet Pregnancy } & elevated \\
\hline
\end{tabular}

telephone allows flexible adaptation of flight plans hospital admissions if needed. ICU equipment (ventilator, monitoring, medication etc.) to manage complications in the pregnant mother is standard; while carrying an incubator, neonatal team and NICU equipment on-board is not reasonable.

In those rare cases in which a transport is no longer possible with an adequate risk - benefit balance and needed neonatal services are not available locally, dispatch of a neonatal team for a planned delivery at the scene with a full set of equipment (incubator, ventilator, surfactant, $\mathrm{HFO}$, iNO, etc.) might be an option.

\section{Conflict of interest}

$\mathrm{MD}, \mathrm{AV}$ and $\mathrm{CR}$ are shareholders / employees of Jetcall $\mathrm{GmbH} \& \mathrm{CoKG}$ and receive a salary from the company. No other author declares any conflict of interest relevant to the content of this article.

\section{References}

1. Kingman CE, Economides DL (2003) Travel in pregnancy: pregnant women's experiences and knowledge of health issues. J Travel Med 10: 330-333. [Crossref]

2. Hezelgrave NL, Whitty CJ, Shennan AH, Chappell LC (2011) Advising on travel during pregnancy. $B M J 342$ : $\mathrm{d} 2506$. [Crossref]

3. Laughon SK, Albert PS, Leishear K, Mendola P (2013) The NICHD Consecutive Pregnancies Study: recurrent preterm delivery by subtype. Am J Obstet Gynecol 210: 131. [Crossref]

4. Tsokos N, Newnham JP, Langford SA (1988) Intravenous tocolytic therapy for long distance aeromedical transport of women in preterm labour in Western Australia. Asia Oceania J Obstet Gynaecol 14: 21-25. [Crossref]

5. Roberts CL, Henderson-Smart D, Ellwood DA (2000) Antenatal transfer of rural women to perinatal centres. High Risk Obstetric and Perinatal Advisory Working Group. Aust N Z J Obstet Gynaecol 40: 377-384. [Crossref]

6. Akl N, Coghlan EA, Nathan EA, Langford SA, Newnham JP (2012) Aeromedical transfer of women at risk of preterm delivery in remote and rural Western Australia: why are there no births in flight? Aust N Z J Obstet Gynaecol 52: 327-333. [Crossref]

7. Connor SB, Lyons TJ (1995) U.S. Air Force aeromedical evacuation of obstetric patients in Europe. Aviat Space Environ Med 66: 1090-1093. [Crossref]

8. Jony L, Baskett TF (2007) Emergency air transport of obstetric patients. J Obstet Gynaecol Can 29: 406-408. [Crossref]

9. O'Brien DJ, Hooker EA, Hignite J, Maughan E (2004) Long-distance fixed-wing transport of obstetrical patients. South Med J 97: 816-818. [Crossref]

10. Samejima T, Nagamatsu T, Iriyama T, Nakayama T, Seyama T, et al. (2020) Impact of additional risk factors on the incidence of preterm delivery among pregnant women diagnosed with short cervix. Taiwan J Obstet Gynecol 59: 195-199. [Crossref]

11. Noveroske RJ (1979) Two applications of the Law of LaPlace to obstetrics. J Indiana State Med Assoc 72: 416-417.

12. Gunnarsson B, Skogvoll E, Jonsdottir IH, Roislien J, Smarason AK (2017) On predicting time to completion for the first stage of spontaneous labor at term in multiparous women. BMC Pregnancy Childbirth 17: 183.

13. Menon R, Richardson LS (2017) Preterm prelabor rupture of the membranes: A disease of the fetal membranes. Semin Perinatol 41: 409-419. [Crossref]

14. Crane JM, Hutchens D (2008) Transvaginal sonographic measurement of cervical length to predict preterm birth in asymptomatic women at increased risk: a systematic review. Ultrasound Obstet Gynecol 31: 579-587. [Crossref]

15. Maia MC, Nomura R, Mendonca F, Rios L, Moron A (2019) Is cervical length evaluated by transvaginal ultrasonography helpful in detecting true preterm labor? J Matern Fetal Neonatal Med 1-7.

16. Conde-Agudelo A, Romero R, Hassan SS, Yeo L (2010) Transvaginal sonographic cervical length for the prediction of spontaneous preterm birth in twin pregnancies: a systematic review and metaanalysis. Am J Obstet Gynecol 203: 128 e1-12. [Crossref]

17. How HY, Khoury JC, Sibai BM (2009) Cervical dilatation on presentation for preterm labor and subsequent preterm birth. Am J Perinatol 26: 1-6. 
18. Foster C, Shennan AH (2014) Fetal fibronectin as a biomarker of preterm labor: a review of the literature and advances in its clinical use. Biomark Med 8: 471-484. [Crossref]

19. Esplin MS, Elovitz MA, Iams JD, Parker CB, Wapner RJ, et al. (2017) Predictive accuracy of serial transvaginal cervical lengths and quantitative vaginal fetal fibronectin levels for spontaneous preterm birth among nulliparous women. JAMA 317: 1047-1056. [Crossref]

20. Murray SR, Stock SJ, Cowan S, Cooper ES, Norman JE (2018) Spontaneous preterm birth prevention in multiple pregnancy. Obstet Gynaecol 20: 57-63. [Crossref]

21. Conde-Agudelo A, Romero R (2016) Cervical phosphorylated insulin-like growth factor binding protein-1 test for the prediction of preterm birth: a systematic review and metaanalysis. Am J Obstet Gynecol 214: 57-73. [Crossref]

22. Fox NS, Saltzman DH, Klauser CK, Peress D, Gutierrez CV, et al. (2009) Prediction of spontaneous preterm birth in asymptomatic twin pregnancies with the use of combined fetal fibronectin and cervical length. Am J Obstet Gynecol 201: 313 e1-5. [Crossref]

23. Fuchs F, Houllier M, Leparco S, Guyot A, Senat MV, et al. (2017) Performance of cervical phIGFBP-1 test alone or combined with short cervical length to predict spontaneous preterm birth in symptomatic women. Sci Rep 7: 10856. [Crossref]

24. Mariona FG, Roura LC (2016) The role of placental alpha microglobulin-1 amnisure in determining the status of the fetal membranes; its association with preterm birth. Traditions ... traditions. J Matern Fetal Neonatal Med 29: 1016-1020.

25. Melchor JC, Khalil A, Wing D, Schleussner E, Surbek D (2018) Prediction of preterm delivery in symptomatic women using PAMG-1, fetal fibronectin and phIGFBP-1 tests: systematic review and meta-analysis. Ultrasound Obstet Gynecol 52: 442-451. [Crossref]

26. Romero R, Conde-Agudelo A, Da Fonseca E, O’Brien JM, Cetingoz E, et al. (2018) Vaginal progesterone for preventing preterm birth and adverse perinatal outcomes in singleton gestations with a short cervix: a meta-analysis of individual patient data. $A m$ J Obstet Gynecol 218: 161-180. [Crossref]

27. Cetingoz E, Cam C, Sakalli M, Karateke A, Celik C, et al. (2011) Progesterone effects on preterm birth in high-risk pregnancies: a randomized placebo-controlled trial. Arch Gynecol Obstet 283: 423-429.

28. Vedel C, Larsen H, Holmskov A, Andreasen KR, Uldbjerg N, et al. (2016) Longterm effects of prenatal progesterone exposure: neurophysiological development and hospital admissions in twins up to 8 years of age. Ultrasound Obstet Gynecol 48: 382389. [Crossref]

29. Berger R, for the Leitlininienkommission der DGGG, SGGG, OEGGG. Prevention and therapy of preterm labour. Guideline of the DGGG, OEGGG and SGGG (S2k-Level, AWMF Registry No. 015/025, February 2019) http: wwwawmforg/leitlinien/detail/ II/015-025html 2019.
30. National Institute for Health and Care Excellence. Mutiple Pregancy: antenatal care for twin and triplet pregnancies. Clinical Guideline No 129, Lomdon, NICE 2011; https:/ www.nice.org.uk/guidance $7 \operatorname{cg} 129$

31. Berghella V, Ciardulli A, Rust OA, To M, Otsuki K, et al. (2017) Cerclage for sonographic short cervix in singleton gestations without prior spontaneous preterm birth: systematic review and meta-analysis of randomized controlled trials using individual patient-level data. Ultrasound Obstet Gynecol 50: 569-577. [Crossref]

32. Saccone G, Ciardulli A, Xodo S, Dugoff L, Ludmir J, et al. (2017) Cervical pessary for preventing preterm birth in twin pregnancies with short cervical length: a systematic review and meta-analysis. J Matern Fetal Neonatal Med 30: 2918-2925. [Crossref]

33. Norman JE, Norrie J, Maclennan G, Cooper D, Whyte S, et al. (2018) Open randomised trial of the (Arabin) pessary to prevent preterm birth in twin pregnancy with health economics and acceptability: STOPPIT-2-a study protocol. BMJ Open 8: e026430. [Crossref]

34. Abramovici A, Cantu J, Jenkins SM (2012) Tocolytic therapy for acute preterm labor. Obstet Gynecol Clin North Am 39: 77-87. [Crossref]

35. Royal College of Obsterticians and Gynecologists. Preterm labour, tocolytic drugs, Green top Guideline No. 18. London, RCOG 2002; https://www.rcog.org.uk/en/ guidelines-research-services/guidelines/gtg $1 \mathrm{~b} /$.

36. Vogel JP, Oladapo OT, Manu A, Gulmezoglu AM, Bahl R (2015) New WHO recommendations to improve the outcomes of preterm birth. Lancet Glob Health 3: e589-e590. [Crossref]

37. Di Renzo GC, Cabero Roura L, Facchinetti F, Helmer H, Hubinont C, et al. (2017) Preterm labor and birth management: recommendations from the european association of perinatal medicine. J Matern Fetal Neonatal Med 30: 2011-2030. [Crossref]

38. Reinebrant HE, Pileggi-Castro C, Romero CL, dos Santos R, Kumar S, et al. (2015) Cyclo-oxygenase (COX) inhibitors for treating preterm labour. Cochrane Database Syst Rev CD001992.

39. Oei SG (2006) Calcium channel blockers for tocolysis: a review of their role and safety following reports of serious adverse events. Eur J Obstet Gynecol Reprod Biol 126 137-145. [Crossref]

40. Vogel JP, Nardin JM, Dowswell T, West HM, Oladapo OT (2014) Combination of tocolytic agents for inhibiting preterm labour. Cochrane Database Syst Rev CD006169. [Crossref]

41. Martin J, Mills J, Stanley D (2017) Is nifedipine as a tocolytic effective in facilitating in utero transfer? Air Med J 36: 122-126. [Crossref]

Copyright: (C2020 Veldman A. This is an open-access article distributed under the terms of the Creative Commons Attribution License, which permits unrestricted use, distribution, and reproduction in any medium, provided the original author and source are credited. 